\title{
The Concepts of Memory, Forgetting and the Past in Toni Morrison's Beloved
}

\section{Toni Morrison’un Beloved Romanında Bellek, Unutma ve Geçmiş Kavramları}

\section{Orkun KOCABIYIK*}

\begin{abstract}
In one's life there has always been a moment or an event that is so shocking and horrific that it is best to try to push it further and further back into your mind. When traumatized, it is very normal to close the memory and for self-defence to suppress the terrible emotional experience. Sometimes this neglecting and abandoning might be the best way to forget, and so do the characters Sethe and Paul D in Toni Morrison's Beloved. Trying to ignore their past and to avoid any related confrontations, they try to forget their terrible memories in Beloved. But, I think this forgetting is very temporary and it lasts only until the smallest event prompts the memory and then the formidable past is experienced once again as painful as it once was. Toni Morrison carries Sethe on a kind of journey from being a woman who identifies herself with motherhood, to a woman who begins to identify herself as being a human being. Morrison brings this picture to life by letting Sethe face her past and bring to mind the events that she worked extremely hard to suppress and to forget. It seems impossible for her to remain in denial of the past. In this paper, I argue that the function of memory concerning the past experiences of the main characters in Beloved (especially Sethe and Paul D) depends upon their spatial and temporal relationships. To support my argument, Paul Ricoeur's theoretical assumptions concerning human memory, together with Daniel L. Schacter's The Seven Sins of Memory, provide the theoretical background for this analysis.
\end{abstract}

Keywords: Memory, Toni Morrison, Past, Social Representation, Trauma

$\ddot{O}_{z:}$ Bir bireyin geçmişinde yaşamış olduğu travmaların gelecekteki yaşamını etkilemesi kaçınılmazdır. $\mathrm{Bu}$ anların etkisinden kurtulmanın en etkili yolu belki de onu bellekte derinlerde bir yerlere itmektir. Travma anlarında unutmaya çalışmak, kişinin kendini koruma altına alması açısından çok normal sayılabilir. Başta öyle görünmese de, bazen bu kabulleniş ve kaçış en iyi yol da olabilir. Tipkı, Toni Morrison'un Beloved adlı romanındaki karakterlerden Sethe ve Paul D'nin yaptığı gibi. Geçmişlerinden kaçmak ve onunla ilgili olaylardan uzaklaşmak için daha önce yaşamış oldukları korkunç olaylardan kaçmaya çalışırlar. Fakat öte yandan, unutmak geçici bir yöntemdir ve daha önce yaşanmış olan kötü deneyimle ilgili herhangi küçük bir anı, onu tekrardan daha etkili ve acı bir biçimde kişinin bilinç düzeyine taşır. Toni Morrison romanında Sethe karakterinin annelikten bir birey olmaya giden yolculuğunu işler. Morrison bu kurguyu Sethe'yi geçmişiyle yüzleştirerek ve bellek düzlemindeki olayları bastırma süreciyle karşımıza çıkartır. Öte yandan Sethe için geçmişini unutmak imkânsız gibidir. Bu çalışmada, Beloved romanındaki ana karakterlerin (özellikle Sethe ve Paul D) geçmiş deneyimlerle ilintili yeni deneyimlerinin, zamansal ve mekânsal düzlemle eş zamanlı değiştiği öne sürülmekte ve geçmiş deneyimlerinin romanın anlatı zamanındaki olayları nasıl etkilediği irdelenmektedir. Bu bağlamda, Paul Ricoeur'un insan belleğinin işleyişiyle ilgili kuramlarının yanı sıra, Daniel L. Schacter'in The Seven Sins of Memory (Belleğin Yedi Günahı) çalışmaları konumuzun kuramsal arka planını oluşturacaktır.

Anahtar sözcükler: Hafiza, Toni Morrison, Geçmiş, Sosyal Temsil, Travma

\footnotetext{
*Yrd. Doç. Dr., Akdeniz Üniversitesi, Edebiyat Fak., İngiliz Dili ve Edeb. Bölümü, Antalya. okocabiyik@akdeniz.edu.tr
} 
Once, I read a short story book titled The First Snow on Fuji by a Nobel Prize winner Japanese writer Yasunari Kawabata. One of these stories titled "Yumiura" in which a novelist, Kasumi, receives a sudden visit from a lady who claims she has known him for 30 years. The lady explains this previous situation, that they met when he visited the city of Yumiura during a festival, but the novelist Kasumi cannot remember her. Plagued recently by other troublesome memory lapses, he sees this incident as a further sign of his mental decline especially when the lady offers more concrete clues about what happened one day when he visited her room as: "You asked me to marry you" she says sadly. Kasumi tries anxiously to recall this while thinking on the magnitude of what he has forgotten. Once more, the lady explains that she has never forgotten their time together and feels continually burdened by her memories of him. After she leaves, Kasumi searches maps for the city of Yumiura with the hope of triggering some recall of the place and the possible reasons why he had gone there. But unfortunately no maps or books list any such city. Kasumi then realizes that he could not have been in the part of the country the lady described at the time she remembered. Though the lady thinks that her memories were accurate, they were entirely false. The essence of Kawabata's story (Kawabata Y. 1999), illustrates different ways in which sometimes memory can get us into difficulty. Sometimes we forget or mystify the past and at other times we distort it. Some disturbing memories might haunt us for years as is the case with Sethe and Paul D in Toni Morrison's Beloved. Trying to ignore their past by avoiding any related confrontations, they try to forget their terrible memories in Beloved. But, one might think that forgetting is temporary and it lasts only until the smallest event prompts the memory and then the formidable past is experienced once again sometimes as painful as it once was. Morrison carries Sethe on a journey from being a woman who identifies herself only with motherhood, to a woman who begins to identify herself as a human being. Morrison brings this picture to life by letting Sethe face her past and bring to mind the events that she had worked extremely hard to suppress or forget; denying her past seems to be impossible for Sethe. In this paper, I argue that the function of memory concerning the past experiences of the main characters in Beloved (especially Sethe and Paul D) depends upon their spatial and temporal relationships both in the individual and the collective levels of the memory. Thus, the foremost aim of this paper is to reveal the mechanism of memory - in terms of re-memory as Morrison puts it in her novel - through the paradigms of Paul Ricoeur on how individual memory shifts into a collective way.

When Morrison was working as editor of a book about African American history namely The Black Book, she added a true story into her edition called "A Visit to the Slave Mother Who Killed Her Child" (Bassett 1856). Actually, this story had already been published in a nineteenth century journal entitled The American Baptist. This anecdote was adopted from a real event concerning Margaret Garner, an African American slave who had run away from the plantation farm to her mother in law's home in Cincinnati and was captured there by her master. Her aim was to protect their four children from the outcome of slavery by killing them but she managed to kill only one of her children; a shocking act resembling the acts of Japanese "Kamikaze" pilots' suicidal attacks during the World War II. In an interview with Alan Benson, Morrison underlined her response to Garner's powerful sense of acting: "For me, it was the ultimate gesture of a loving mother. It was also the outrageous claim of a slave. The last thing a slave woman owns in her children" (qtd. in Benson 1987). Although Morrison's aim in Beloved was to create a novel not a linear history, the plotline elements of the novel were affected by the historical record, especially by the story of Garner.

In most of her novels, Morrison focuses on past events and their influences on the present. One might easily capture in Morrison's novels that she manifests her characters stuck in their 
past actions and their outcomes as in The Bluest Eye (1970) or Home (2012). Morrison describes her own motivation for inserting this historical preoccupation in her works: "There is infinitely more past than there is future...The past is infinite" (Fowler \& Abedie qtd. in Kolmerten \& Wittenberg 1997, 27). This "infinite past" is one of the repeating motifs in Morrison's works and she persistently comments on this here and there. Morrison's own non-linear family history also contributes to this focus because she has strong influences from her parents. For example, in one of the interviews held with Morrison, she explains how the impact was big when she first heard of Alabama slavery from her grandfather. Moreover, "these familial ties have influenced Morrison's geographical awareness, as her parents' and grandparents' stories of their lives in Alabama and Georgia gave her a sensibility of the US South not always available in such communities as Lorain, Ohio, where she was born and raised" (Denard 1997, 178).

At the beginning of the story, the author pictures a group of protagonists namely Sethe, Denver, and Paul D. However, there appears another character that takes central stage for the greater part of the story, namely Beloved. Before highlighting the importance of Beloved in terms of re-memory connected with the chronology of the novel, it might perhaps be useful to quote a passage from the Foreword to the 2005 Vintage edition of the book:

"She worked out of the water, climbed the rocks, and leaned against the gazebo. Nice hat. So she was there from the beginning... The figure most central to the story would have to be her, the murdered, not the murderer, the one who lost everything and had no say in any of it. She could not linger outside; she would have to enter the house... One with an address, one where former slaves experience intimate, I hoped the sense of things being both under control and out of control would be persuasive throughout; that the order and quietude of everyday life would be violently disrupted by the chaos of the needy dead; that the herculean effort to forget would be threatened by memory desperate to stay alive. To render enslavement as a personal experience, language must get out of the way" (Morrison 2005, xii-xiii).

Upon her return to 124 - a house in Ohio - Beloved appears in the body of a young woman with a saw scar under her chin, a reminder of Sethe's murderous hand when, some 18 years earlier, she killed her baby girl to protect the child from the outcomes of slavery and rape. While many critics interpret Beloved as Sethe's guilty conscience, Beloved is also symbolically seen as a representative of the "Sixty Million and more" (Morrison 2005). In the epigraph to her novel, Morrison refers to slaves who lived and died in slavery from the beginning of the Atlantic slave trade to the American continent until the end of the Civil War. More allegorically, Beloved is "alluded to as the ghost of Everyman who lost life during those high death-rate overseas crossings loaded with human cargo" (Harris 1991; Jennings 2008 qtd. in Kotecki 2013, 934).

When the case of the novel is considered, remembering can be seen as a creative and mental process associated with recollecting past events, while memory is regarded as a conscious act. Along with the terms remembrance and memory, there appears in the novel another term, "rememory". Memory being a passive and static force dependent on the rememberer (more individual), while "re-memory", sounds as if it is an active power independent of the one who remembers (more collective and past oriented). Therefore, it is possible to revisit memories, both physically and mentally and, as such, it spans between the region between personal memory and collective memory making past and present mingle which intensifies memory through making it more dynamic. To understand this process, one will need to mention Paul Ricoeur's 
thoughts on personal and collective memory. As Lavenne, Renard, and Tollet observed in their "Fiction, Between Inner Life and Collective Memory. A Methodological Reflection", different scholars have held various standpoints on memory. On the one hand, the researchers mention a school that the French philosopher Ricoeur called "the tradition of inwardness" (Lavenne et al. $2005,1)$, which conceptualized memory as an individual act. In short, according to this school, memory is seen as a "subjective experience and memories are believed to belong to the individual" (1-2).

According to Ricoeur, "memory must belong to the realm of interiority because individuals see themselves as the true possessors of their own memories" (Lavenne et al. 2005). However, as he later admitted, "memory also involves 'the other' and fully bears its mark" (2). Indeed, it is possible to say that when "memory enters the public sphere it becomes a testimony which is always presented to, and received by, an other" (Lavenne et al. 2005, 3). This collective memory becomes a framework within which the individual memory is constructed and structured. This framework is also the case in Beloved in that the individual histories pass into collective levels of the proposed non-linear history of African-Americans. This also means Sethe's history becomes African-Americans' collective history.

Sethe was confronted in her enslaved life with the most terrifying experiences. Her life was full of loss, fright and abuse as she says in the beginning "everybody I knew was dead or gone or dead and gone" (Morrison 2005, 50); it was a life full of anguish and sorrow. Starting for her childhood when her mother turned her back on her, "Not even her own mother... turned away from her..." (30). Afterwards the way she was treated by the schoolteacher, Mr. Garner was death; her milk was stolen; she was left by her husband; she escaped from the plantation in a pregnant state and delivered her child in the middle of nowhere; and finally the worst, killed her baby girl with her own hands. These events would drive any other person completely insane, but Sethe was strong and she found a way to survive for a while; denial, but it did not work forever because a supernatural being (Beloved) haunted both her and the household.

The time she spent at Sweet Home plantation when she was having quite an ordinary life in the early years after her arrival cost her a dozen times more than she enjoyed it. She believed that she was able to live a peaceful life, but eventually that turned out to be utterly impossible. Sethe was desperate to forget not only the bad memories, but also the things she once had allowed herself to feel and to have; such as love and hope, these she tried to leave behind. This was supposed to keep her from getting mad by being captured by her terrible past. Sethe tries hard to forget her past slavery and start living anew. At 124 she seeks to make a fresh start, cleansing her thoughts and working for "beating up the past" and trying to create a shiny future, "the future was sunset; the past something to leave behind. And if it didn't stay behind, well. You might have to stomp it out" (302). When Denver wants to hear stories about her mother's life, Sethe refuses to tell her anything from the past except the story of her birth. In this way she tries to keep her distance from the memories to prevent them from intruding into the present. She herself is obsessed with that past and thinks of it as a dangerous force which keeps on haunting her. The best she can do to protect her daughter from the terrifying experiences she has had is to forget them herself. "To Sethe, the future was a matter of keeping the past at bay....as for Denver, the job Sethe had of keeping her from the past that was still waiting for her was all that mattered" (51). But this job was a task impossible to fulfil. By Paul D's arrival and Beloved's appearance there was no way for her to keep on denying that history:

"Through the door straight into a pool of red and undulating light that locked him where he stood... 'You got Company?', he whispered, frowning. 
'Off and on', said Sethe. 'Good God'. He backed out of the door onto the porch. 'What kind of evil you got in here?' 'It is not evil, just sad. Come on. Just keep through' "' (10).

Sethe had pushed both awakened emotions and flashbacks, far back into her immense box of dark memories. As for Paul D, he revealed Sethe's feminine side, which she had put aside and had forgotten that she had one. "Emotions sped to the surface in his company. Things became what they were: drabness looked drab; heat was hot. Windows suddenly had view. And wouldn't you know he'd be a singing man" (48). Sethe shared a past with him, he simply knew the most of what she had gone through saying, "thank God I don't have to re-memory or say a thing because you know it" (226). It was relieving for her to talk to him about things she couldn't bring up or even think about in anyone else's presence. But Paul D himself had chosen the same way as Sethe had to be able to move on: forgetting the past. For him too, it was hard to talk about the things that had happened. It was his "tobacco tin", in which he had stored all the misery and feelings, good or bad. Like Sethe, he, too, was confronting a struggle with his dark history of past that "...he could put Alfred, Georgia... one by one, into the tobacco tin lodged in his chest. By the time he got to 124 nothing in this world could pry it open" (133). At the same time, those shut off memories were unconsciously deteriorating his soul, not allowing him to sense and to live. He was afraid of letting the past float; he was frightened of his own reaction to these and doubted if he could ever handle them again. But the fact was that the return of the memories was completely inevitable at 124 . With the appearance of Beloved, there were no memories that could be kept hidden. She forced both Sethe and Paul D to open up and to remember and give in to the power of the past and to face their deep emotions and desires. It took a while, but Sethe eventually admitted that Beloved was her baby girl which she had murdered in order to free her from the hands of cruelty. She learnt to accept the truth though it was as horrifying as hell... She stopped running away from it and stood up firmly trying to confront the consequences of her actions in the past. She confessed to Paul D what she had done to Beloved and accepted his reaction, understanding that he would have trouble agreeing with her and supporting her decision. Her direct confrontation with Beloved was also very relieving for Sethe:

$$
\begin{aligned}
& \text { "You rememory me?" } \\
& \text { "Yes. I remember you." } \\
& \text { "You never forgot me?" } \\
& \text { "Your face is mine" (215). }
\end{aligned}
$$

Sethe could remember her daughter no matter what had happened. Every aspect of hers was fresh in her memory although she had always tried very hard not to dwell on her. Now, Beloved was there with her, she was able to re-live her past, spend time with her daughter and gain some inner-peace. By trying to forget her roots and history, Sethe was suppressing her real identity and the real her as an individual. Hiding her feelings and emotions had made of her an insensitive rock, not caring for anything, even in regard to Denver, her daughter, who was born on the Ohio River and never experienced slavery herself but only learned of it from her mother. She didn't give her daughter the attention she needed at that crucial age. Denver felt mostly deserted; the only company she had left with was the ghost of her sister. So Sethe fought getting mad but eventually the memories started to take charge, but re-memory saved Sethe. Those who cannot let go of the past cause self-destruction and those who do let go of the past choose to respect and accept it and to mourn for the past find unexpected freedom. 
Paul D was another to experience that. It was when he gave in to Beloved's seduction and in a sense also gave in to his own desires that he had forgotten that he had. "...he didn't hear the whisper that the flakes of rust made either as they fell away from the seams of his tobacco tin. So when the lid gave away he didn't know it. What he knew was that when he reached the inside part he was saying, Red heart. Red heart. Red heart..." (138). At this very moment the "tobacco tin" fell open and Paul D could feel all the emotions he had hidden for a very long time. The enormous float of these feelings and desires overwhelming them was very difficult to handle but when it was over it would be his freedom of the prison house of the past. It was at that time when Paul D noticed the actual "color of his heart"; he realized that he was really alive and was able to feel. It was like he was feeling and experiencing all the pains and pleasures he had before, but now all at once; re-memory. Afterwards, he was freed and was really ready to move on, as was the case with Sethe.

Every single experience one has in his or her life is stored, whether wished for or not. The memory is always present. The only way of being able to deal with the future and actually enjoying it is to confront with and accept the past. Hence, whatever the characters choose to do with their memories will shape their future. Sethe is struggling in a process of self-negation by neglecting and denying her past by suppressing her own identity. Her struggle with her memory is almost eating up her feeling of "self". But re-memory, confrontation with the past, dealing with it and giving her memories a legitimate place in her existence, help her to move on. Though re-memory can be rather freeing, it seems that there are times that it is for the best to forget. "They forgot her like a bad dream... remembering seemed unwise" (323-324). Beloved should be forgotten for the sake of everyone.

For a better understanding of the perpetual past and present memory, one might turn to Ricoeur who pointed out his thoughts on memory in his seminal study Memory, History, Forgetting (2004). He defines the dynamic nature of memory by saying that "the collective memory is a kind of storage of individual blows, wounds and scars" (Ricoeur 9). Based on the dynamic nature of memory, this mechanism allows the spirit/fleshed Beloved to move freely between past and present moments, as she does between the individual and the collective zones. Such chronological backward/forward flashbacks enable Beloved to metaphysically assume the role of an eyewitness of the sufferings of the slaves until the Civil War in America, only to return later in the novel to 124 with harder claims upon her guilty mother. After returning to the story's fictional present, the pregnant and demanding Beloved is exorcised a second and last time by a group of women in the neighbourhood. After this collective act of exorcism, the haunting history is finally left to rest, as are the personal and shared memories of the slavery past:

"They forgot her like a bad dream. After they made up their tales, shaped and decorated them, those that saw her that day on the porch quickly and deliberately forgot her. It took longer for those who had spoken to her, lived with her, fallen in love with her, to forget... So they forgot her. Like an unpleasant dream during a troubling sleep... Down by the stream in back of 124 her footprints come and go, come and go. They are so familiar... By and by all trace is gone, and what is forgotten is not only the footprints but the water too and what is down there. The rest is weather... Just weather... Beloved" (Morrison 2005, 323-324).

In the beginning, this group of women of the neighbourhood help Sethe and Denver by giving them some daily goods. Later, "when they learn, however, that the ghost of the baby girl has come back in flesh, and is slowly consummating Sethe" (Değirmenci 2008, 57) they act together 
for exorcism. They come together in front of their house and held a kind of collective ritual. As was highlighted in many chapters of the novel by Morrison, the concept of remembering and past in terms of memories in Beloved is problematic. What happens to "Beloved" is explained at the end of the novel: "Disremembered and unaccounted for, she cannot be lost because no one is looking for her, and even if they were, how can they call her if they don't know her name? Although she has claim, she is not claimed" (Morrison 2005, 274). As a result, after prying open their 'tobacco tin lodged chests' wandering in their 're-memories' after experiencing their past incidents in full view and with its painful colours, facing it without the shame of forgetting it. After that, they leave 'Beloved' behind and get to some place for constructing a new future. Christian asserts that Beloved is more than just a novel. She defines this novel as "a prayer, a healing ritual for our country's holocaust of slavery" (Christian 1993). Morrison offers a way to construct their identities, to those African American people who still stand in the mid of the burden of slavery. The characters in the novel whose identities are paralysed by slavery, find a means to reconstruct themselves only through remembering their past memories.

In her Beloved, Morrison sheds light upon the traumatic past of African American slavery. With her characters who used to be slaves, Morrison narrates the inhumanity of slavery and the pain it caused for this community. Sethe, Paul D, Stamp Paid, Baby Suggs went back to their undeniable past, whether they want it or not. When Beloved as a young girl (ghost), came into their life to live with Sethe, their lives also change. Throughout the novel, Beloved is reflected as all the others' past, as well as the reincarnation of Sethe's baby girl, pushing them to remember their undeniable past and to face it. Through this reconciliation, they will have the chance of survival. The community has also a great importance for these characters; they need each other because of their shared collective memories. Through the stories of these former slaves, the next generation might understand their ancestors' past. As they face their memories the characters begin to heal, "African American people need to remember their painful collective past to situate themselves more firmly in the world they live in" (Değirmenci 2008, 63).

In Beloved, African American non-linear slave history is the main point of the novel. Even if it is traumatizing, this common past is what makes people come together. No matter how painful the outcomes of slavery are, it is part of their character. Morrison deals with the national forgetfulness on slavery and its painful remembrances through this novel. It is with Beloved, that Morrison makes her characters remember their past. 


\section{REFERENCES}

Bassett P. C. (1856). "A Visit to the Slave Mother Who Killed Her Child". National Anti-Slavery Standard (1856) 1. New York.

Barbara C. (1993). Toni Morrison: Our Saving Grace. Source: http://garnet.berkeley.edu: 3333/.mags/ .38/.black/.bmorris.html. Accessed on 14 June 2016.

Değirmenci A. (2008). Collective Memory and Social Memory in Contemporary Fiction by Ethnic Women Writers: Louise Erdrich's 'Tracks', Toni Morrison's 'Beloved', and Sandra Cisnero's 'Caramelo'. Ankara 2008.

Denard C. C. (1997). "Beyond the Bitterness of History: Teaching Beloved". Eds. N. N. McKay \& K. Earle, Approaches to Teaching the Novels of Toni Morrison (1997) 48-55. New York.

Fowler D. \& Ann J. A. (1997). "Reading For the 'Other Side': Beloved and Requiem for a Nun". Eds. C. A. Kolmerten, J. B. Wittenberg \& S. M. Ross, Unflinching Gaze: Morrison and Faulkner ReEnvisioned (1997) 139-151.

Jennings L. V. D. (2008). Toni Morrison and the Idea of Africa. New York 2008.

Kawabata Y. (1999). The First Snow on Fuji. Trans. M. Emmerich. Washington 1999.

Kotecki G. (2013). "The Ghost Daughter Returns Home: Memory of Slavery in Toni Morrison's Beloved". Sociology Study 12/3 (2013) 933-940.

Lavenne F. -X., Renard V. \& Tollet F. (n.d.). "Fiction Between Inner Life and Collective Memory. A Methodological Reflection". The New Arcadia Review. Published online http://www.bc.edu/ publications/newarcadia/archives/3/fiction/

Morrison T. (2005). Beloved. London 2005.

Ricoeur P. (2006). Memory, History, Forgetting. Chicago and London 2006. 